\title{
Ultra-high-resolution seasonality of trace-ion species and oxygen isotope ratios in Antarctic firn over four annual cycles
}

\author{
Alison McMORROW, ${ }^{1 *}$ Tas D. VAN OMMEN, ${ }^{2}$ Vin MORGAN, ${ }^{2}$ Mark A. J. CURRAN ${ }^{2}$ \\ ${ }^{1}$ Institute of Antarctic and Southern Ocean Studies and Antarctic Climate and Ecosystems CRC, Private Bag 77, Hobart, \\ Tasmania 7001, Australia \\ E-mail: Alison.McMorrow@deh.gov.au \\ ${ }^{2}$ Australian Antarctic Division and Antarctic Climate and Ecosystems CRC, Private Bag 80, Hobart, Tasmania 7001, Australia
}

\begin{abstract}
Ultra-high-resolution firn-core records covering four annual cycles of oxygen isotope ratios $\left(\delta^{18} \mathrm{O}\right)$ and trace-ion species were generated from a high-accumulation site on Law Dome, East Antarctica. Event-scale dating of the records was established using hourly snow accumulation measurements from a co-located automatic weather station (AWS). These net accumulation events were used to examine the seasonal timing of $\delta^{18} \mathrm{O}$ and a suite of trace-ion species including marine biogenic sulphur compounds (methanesulphonic acid (MSA), non-sea salt sulphate), nitrate and major sea-salt species (sodium, chloride, magnesium). The ultra-high-resolution nature of this study and independent dating scale provide an opportunity to examine exact timings in the seasonality of each species. The traditional summer-maximum species of $\delta^{18} \mathrm{O}$ and MSA show consistent relative phasing during midsummer over the four annual cycles. Nitrate shows an erratic seasonal cycle with a general trend characterized by narrow peaks during spring and early summer, preceding the mid-summer peaks in $\delta^{18} \mathrm{O}$ and MSA. Non-sea-salt sulphate cycles indicate similar characteristics to MSA signals during summer, but are more comparable to nitrate signals during spring, autumn and winter. This suggests the summer non-sea-salt sulphate signal is driven by biological activity, although this species appears to be linked with nitrate signals outside the summer season. Finally, the sea-salt species indicate a seasonal cycle characterized by maximum concentrations during spring, winter and autumn. Event-scale dating of the firn-core records allows direct comparisons between the seasonal cycles and meteorological conditions. Contemporaneous local air-temperature measurements are compared with the highresolution $\delta^{18} \mathrm{O}$ record. This allows a detailed investigation of the relationship between site temperature and $\delta^{18} \mathrm{O}$ signals in the ice core.
\end{abstract}

\section{INTRODUCTION}

Deep ice-core records from polar regions provide a powerful tool for understanding atmospheric forcing and potential consequences of global climate change. Investigation of the variability in ice-core signals enables a reconstruction of climate cycles on a range of time-scales ranging from seasonal to glacial-interglacial fluctuations. Deep ice cores provide a reconstruction of climate signals that address some of the biggest questions facing environmental scientists today, including the impact of anthropogenically induced global climate change. The absence of instrumental climate records over longer time-frames requires the use of highresolution, modern ice-core studies to validate the deep icecore record. Defining the seasonal cycle for isotopic and chemical species enables a greater understanding of the source regions and transport mechanisms influencing the deep ice-core signal.

The Dome Summit South (DSS) ice core provides highresolution climatic and environmental information through the Holocene and the last glacial period (e.g. Morgan and van Ommen, 1997; Morgan and others 1997; Delmotte and others, 1999; Palmer and others, 2001). The DSS site is situated $4.6 \mathrm{~km}$ south-southwest of the Law Dome summit,

*Present address: Technology Futures Team, Australian Greenhouse Office, Department of the Environment and Heritage, John Gorton Building, GPO Box 787, Canberra, ACT 2601, Australia.
East Antarctica (Fig. 1), and offers an ideal site for the investigation of isotopic and chemical signals in fine detail. Law Dome is located at the edge of the main East Antarctic ice sheet, and projects into the predominately easterly atmospheric circulation produced by the quasi-stationary

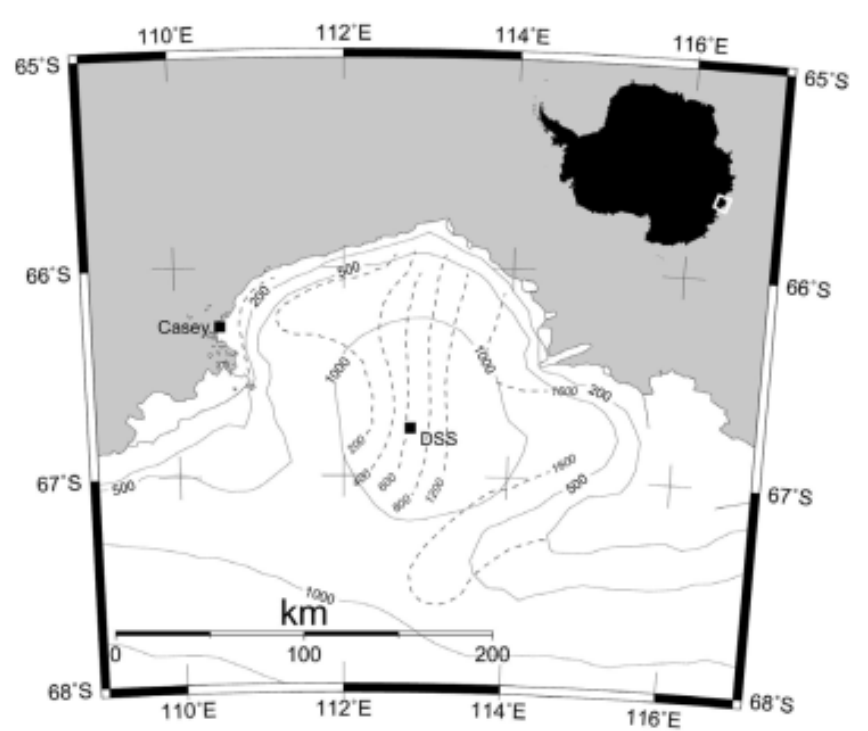

Fig. 1. Location map for Law Dome, with DSS sampling site and Casey station marked. Elevation (solid) and accumulation (dashed) contours are shown. 


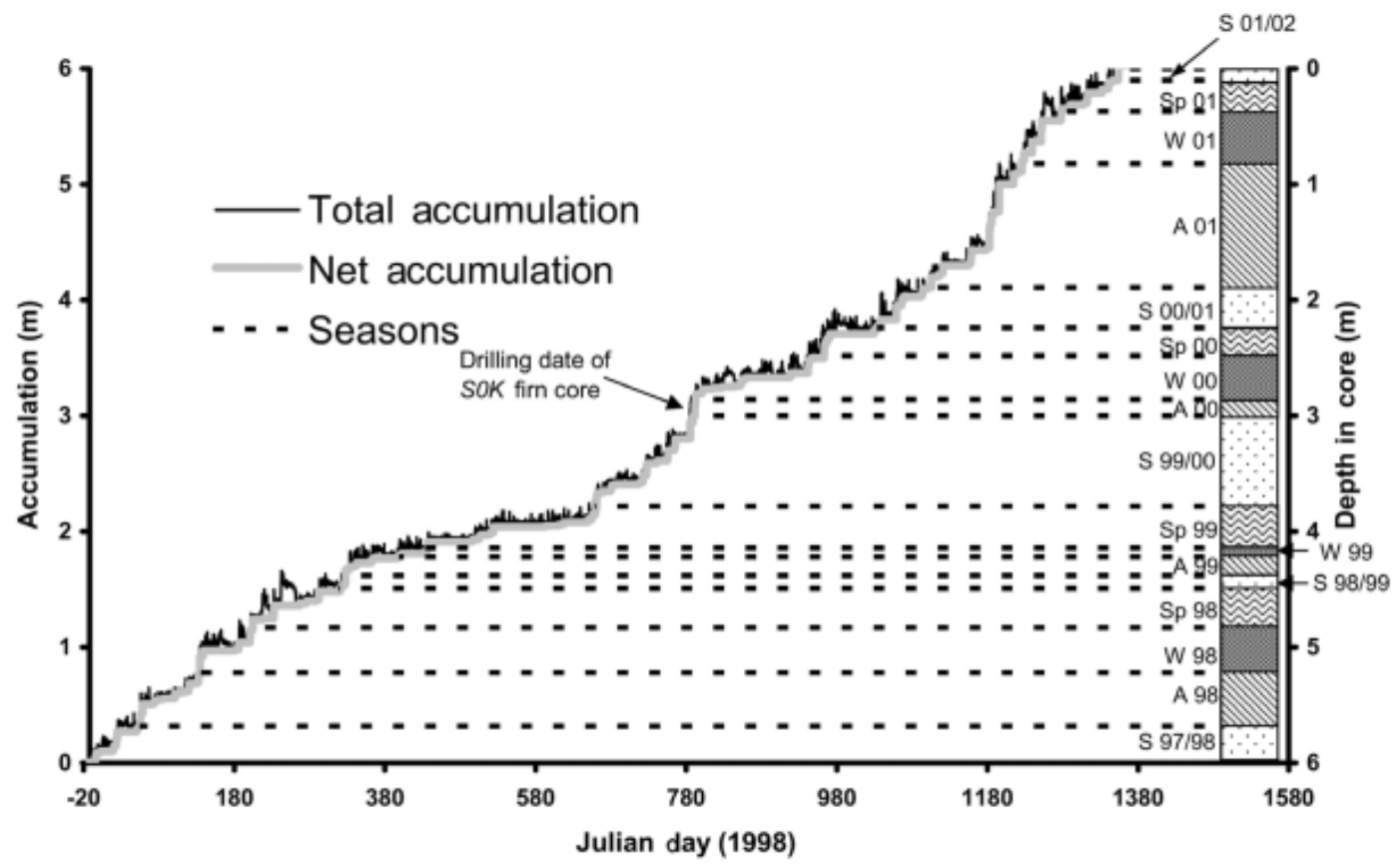

Fig. 2. Total and net snow accumulation recorded from the AWS from 21 December 1997 (Julian day 10) to 24 December 2001 (Julian day 1454). Net accumulation from each austral season is shown (summer (S), autumn (A), winter (W), spring (Sp)) to make up the DSS0102 firn core that was drilled on 24 December 2001. Drilling date of the SOk firn core (6 March 2000: Julian day 796) is also shown.

cyclone situated to the northeast of Law Dome (Bromwich, 1988). Cyclonic systems frequently pass to the north of Law Dome, producing high accumulation rates of approximately $0.7 \mathrm{ma}^{-1}$ ice equivalent for sites near the summit of the Dome (Morgan and others, 1997). This high annual accumulation leads to the deposition of thick annual layers, allowing the extraction of isotopic and chemical records with sub-annual resolution. The absence of high wind gusts at DSS (Adams, 1996) minimizes surface mixing and redistribution of snow, and low mean summer temperatures $\left(-12.6^{\circ} \mathrm{C}\right)$ (Allison and others, 1993) preclude summer melt. These conditions limit disturbance of the chemical archive preserved in the firn.

Seasonal signals of the oxygen isotope ratio $\left(\delta^{18} \mathrm{O}\right)$ and trace chemical species are well defined in the DSS ice core (Morgan and others, 1997; Curran and others, 1998), and agree well with ice-core studies from other Antarctic sites (e.g. Bradley and Jones, 1993; Minikin and others, 1998; Wagenbach and others, 1998a). Previous seasonality studies have tended to determine the sub-annual chronology using the seasonal cycle of well-understood species such as $\delta^{18} \mathrm{O}$ (e.g. Whitlow and others, 1992), or by calculating composite seasonal signals by stacking data from cores covering a number of years (Morgan and van Ommen, 1997; Curran and others, 1998; Palmer, 2002). In contrast, the results presented in this paper examine the seasonal cycle of trace chemical and isotopic species using a chronology that is independent of the seasonality of the signals under investigation.

\section{METHODS AND SAMPLE COLLECTION}

The results presented here draw on material from two shallow $(10 \mathrm{~m})$ firn cores drilled at the DSS site on Law Dome (Fig. 1). The first core (SOk) was collected during the $1999 / 2000$ austral summer season, and the second core (DSS0102) was collected during the 2001/02 austral summer season. Both cores were drilled with a hand auger with special care taken to preserve the top $0.3 \mathrm{~m}$ section of friable material. The cores were transported frozen back to Australia and sampled for $\delta^{18} \mathrm{O}$ and trace-ion chemical species at $2.5 \mathrm{~cm}$ resolution using established techniques (Curran and Palmer, 2001; McMorrow and others, 2001). The SOk and DSS0102 firn cores were drilled approximately $500 \mathrm{~m}$ apart. The top $3 \mathrm{~m}$ of the SOk firn core, collected during the first season (1999/2000), preserves material from summer 1999/2000 back to the installation of the automatic weather station (AWS) during summer 1997/98. This section overlaps with the 3-6m section of the DSS0102 firn core, collected during the second season (2001/02), and preserves material from summer 2001/02 back to the installation of the AWS. Previous studies on Law Dome snow-pit and firn-core records have reported excellent spatial reproducibility from chemical and isotopic records up to $7.7 \mathrm{~km}$ apart (McMorrow and others, 2001, 2002), allowing confidence in identifying regional climatic signals in Law Dome firn cores.

\section{DATING THE FIRN CORES}

High-resolution dating of the SOk and DSS0102 firn cores was established using snow accumulation measured directly over the core site by an AWS located $50 \mathrm{~m}$ west of the SOk firn core. Meteorological events that make up $S O k$ and DSS0102 are identified using techniques developed in previous studies (McMorrow and others, 2001, 2002). Net accumulation of snow is made up of accumulated snowfall and subsequent snow removal through ablation and wind scouring of the surface (Fig. 2). In addition, compaction of the snowpack results in a perceived loss of snow for the AWS accumulation sensor. Net accumulation steps preserved in the firn-core records are grouped into events using two considerations. First, accumulation steps which occur close together in time $(<1$ week) and from a particular synoptic 


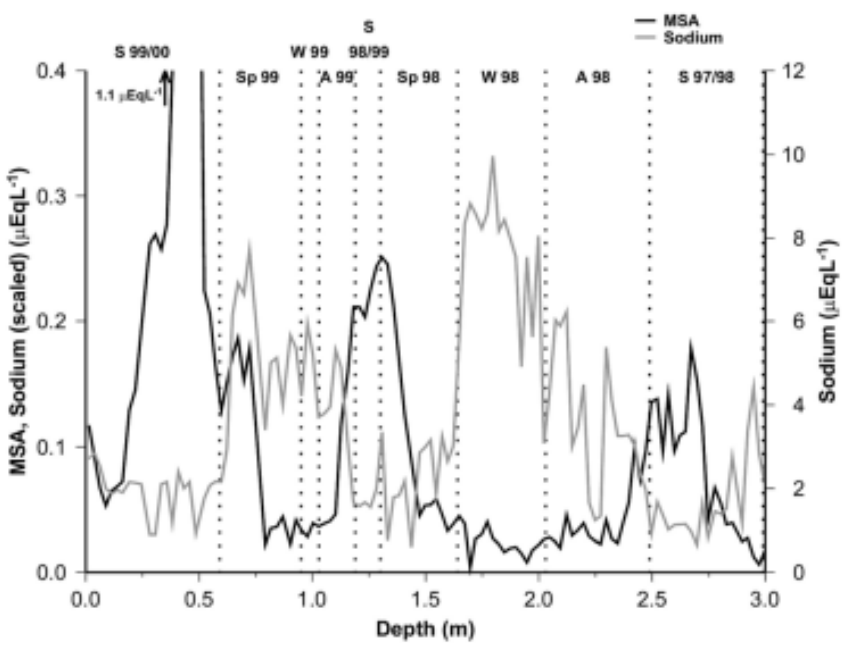

Fig. 3. MSA and sodium records preserved in SOk for the $0-3 \mathrm{~m}$ depth range. Seasonal (dotted line) boundaries determined from the AWS are also shown.

situation are grouped into a single event. Second, the chemical and isotopic signature for each event is examined, and events characterized by a sharp change in chemical or isotopic signals within a short time period are separated into distinct events. This separation allows the investigation of sharp changes in the glaciochemical record that occur over consecutive days or within a particular synoptic system. Grouping the accumulation events using these techniques identifies 27 events preserved in the time period covered by SOK and 24 events in DSSO102. The 27 events identified in SOk are also preserved in the 3-6 $\mathrm{m}$ section of the DSSO102 firn core. The most recent time period sampled (summer 2001/02) corresponds to the top section of the DSS0102 firn core, and the record extends down to event 51 identified in SOk (and DSS0102) and snow preserved during winter 1998 (Fig. 2).

\section{EFFECTS OF DENSIFICATION OF THE SNOWPACK}

The deposition of snow on the ice sheet is an episodic process, and over time the snow accumulation compresses the snow beneath it. This has the potential to introduce large uncertainties in dating high-resolution firn-core records using snow height changes from the AWS. Densification results in a perceived loss of snow from the snow accumulation sensor mounted on the AWS, yet the compacted snow is retained in the firn-core record. The identification of events at depth needs to be interpreted with caution due to the potential impact of densification. The collection of firn cores from two distinct seasons that cover the same time period allows the investigation of potential density effects on the dated records.

\section{Season $1-S O k$}

The top $3 \mathrm{~m}$ of the SOk firn core, collected during the first season (1999/2000), preserves material from summer $1999 / 2000$ back to the installation of the AWS during summer 1997/98. This core section preserves chemical and isotopic signals consistent with two seasonal cycles identified from the AWS dating scale. The summer species (MSA, $\delta^{18} \mathrm{O}$ (not shown), nitrate (not shown) and non-sea-salt sulphate (not shown)) are in phase with the summer periods

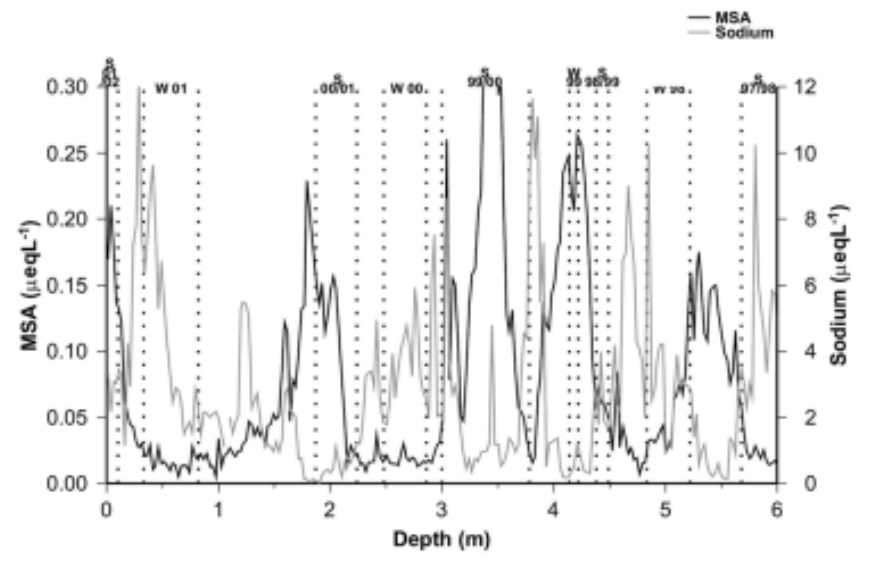

Fig. 4. MSA and sodium records preserved in DSS0102 for the 0-6 $\mathrm{m}$ depth range. Seasonal (dotted line) boundaries determined from the AWS are also shown.

of the AWS dating scale, while sea-salt concentrations (sodium, chloride (not shown) and magnesium (not shown)) are preserved during winter deposition layers (Fig. 3). This is consistent with previous high-resolution studies that resolve the seasonal cycle of ice-core signals both at the Law Dome site (Curran and others, 1998) and at other Antarctic sites (Legrand and Delmas, 1984; Minikin and others, 1994; Kreutz and others, 1999). These results suggest that densification over the top $3 \mathrm{~m}$ of the snowpack does not significantly affect the dating of events at the seasonal scale at Law Dome.

\section{Season 2 - DSS0102}

The DSSO102 firn core was collected 2 years later than SOk, and the top $6 \mathrm{~m}$ of DSSO102 covers the period from summer 2001/02 back to the installation of the AWS during summer $1997 / 98$ (Fig. 2). The core section $3-6 \mathrm{~m}$ in DSSO102 overlaps with the time period preserved in the core section $0-3 \mathrm{~m}$ in SOk. Figure 4 illustrates that for the top $3 \mathrm{~m}$ of the snowpack the seasonal cycles of the chemical and isotopic signals are in phase with the AWS dating scale. This is consistent with the results presented in Figure 3 and confirms that the top $3 \mathrm{~m}$ of the snowpack is not significantly affected by densification at the seasonal time-scale. However, for depths $>3 \mathrm{~m}$ the impact of densification becomes increasingly more pronounced and the firn-core record compacts significantly compared to the AWS dating scale (Fig. 4). This is indicated by the seasonal signals in the firn core becoming out of phase with the seasonal boundaries identified in the AWS dating scale. For example, the clear summer peak in MSA at $5.25 \mathrm{~m}$ depth is identified from the AWS dating scale as occurring during autumn 1998 (Fig. 4). This same summer peak is identified in the SOk firn core at around $2.5 \mathrm{~m}$ depth and identified from the AWS dating scale as occurring during summer 1997/98 (Fig. 3).

\section{Correcting for densification - DSS0102}

The AWS dating scale may be 'corrected' for depths $>3 \mathrm{~m}$ by considering the amount of densification for events preserved in both the SOk and DSSO102 firn cores. Figure 5 illustrates the effect of compacting the AWS dating scale for DSSO102 to bring the seasonal signals in the firn core in phase with seasons identified from the AWS net accumulation record. The AWS dating scale 'correction' was calculated using an 
interpolative method considering significant chemical and $\delta^{18} \mathrm{O}$ events preserved in both firn cores. Nineteen significant events were identified in both the SOK and DSSO102 firn cores. The depth of each event in the firn cores was used as a known input range, and a simple linear interpolation was conducted on the AWS dating scale. This resulted in 'compacting' the AWS dating scale with respect to the DSS0102 firn core to bring the significant events in line with the dates identified from the SOk firn core.

\section{SEASONALITY OF $\delta^{18}$ O AND TRACE ION SPECIES OVER FOUR ANNUAL CYCLES}

The use of the AWS accumulation record to accurately date high-resolution firn-core records provides a unique opportunity to examine the seasonality of chemical and isotopic signals preserved in the ice core.

\section{MSA}

The marine biogenic signal represented by MSA in DSSO102 shows a clear seasonal signal for the four annual cycles, with maximum concentrations occurring during summer, and minima during autumn, winter and spring (Fig. 5). The record is characterized by sharp boundaries either side of the summer peak, with few additional peaks preserved through the remaining annual cycle. The main summer MSA peak tends to occur simultaneously with the main midsummer $\delta^{18} \mathrm{O}$ peak. These results are consistent with MSA sourced from DMS production during summer marine biogenic activity. Non-summer MSA peaks are much smaller and confined to either late-summer/early-autumn or spring events. These events are also generally characterized by elevated levels in $\delta^{18} \mathrm{O}$, sea salts and nitrate (Fig. 5). Previous studies have attributed similar events to the intrusion of lowlatitude air through strong cyclonic systems (McMorrow and others, 2001, 2002).

\section{Sea salts}

The major sea-salt species (sodium, chloride, magnesium) preserved in DSSO102 reflect a noisy record, although maximum concentrations tend to be preserved during spring, winter and autumn, and minimum levels during summer (Fig. 5). This is in general agreement with previous studies from coastal Antarctic sites where higher levels of sea salts are preserved during the austral winter (Minikin and others, 1994; Curran and others, 1998; Wagenbach and others, 1998a). The noisy nature of the sea-salt species indicates the record is driven by specific events rather than the broad seasonality in climate conditions. High winter seasalt concentrations are consistent with increased frequency of cyclonic events in the Antarctic region during winter (King and Turner, 1997). The fine-resolution sampling of DSS0102, coupled with the accurate, independent dating scale, allows the extension of the sea-salt seasonal cycle to include maximum concentrations preserved during spring and autumn. This result is consistent with the synoptic-scale meteorology for these seasons. Meteorological studies for the East Antarctic region report a semi-annual variation in atmospheric pressure with minimum pressures observed in the austral spring and autumn (Schwerdtfeger, 1984; Allison and others, 1993; King and Turner, 1997). Atmospheric pressure minima in the Southern Ocean are associated with more intense cyclonic systems characterized by stronger surface winds. These strong winds provide the mechanism
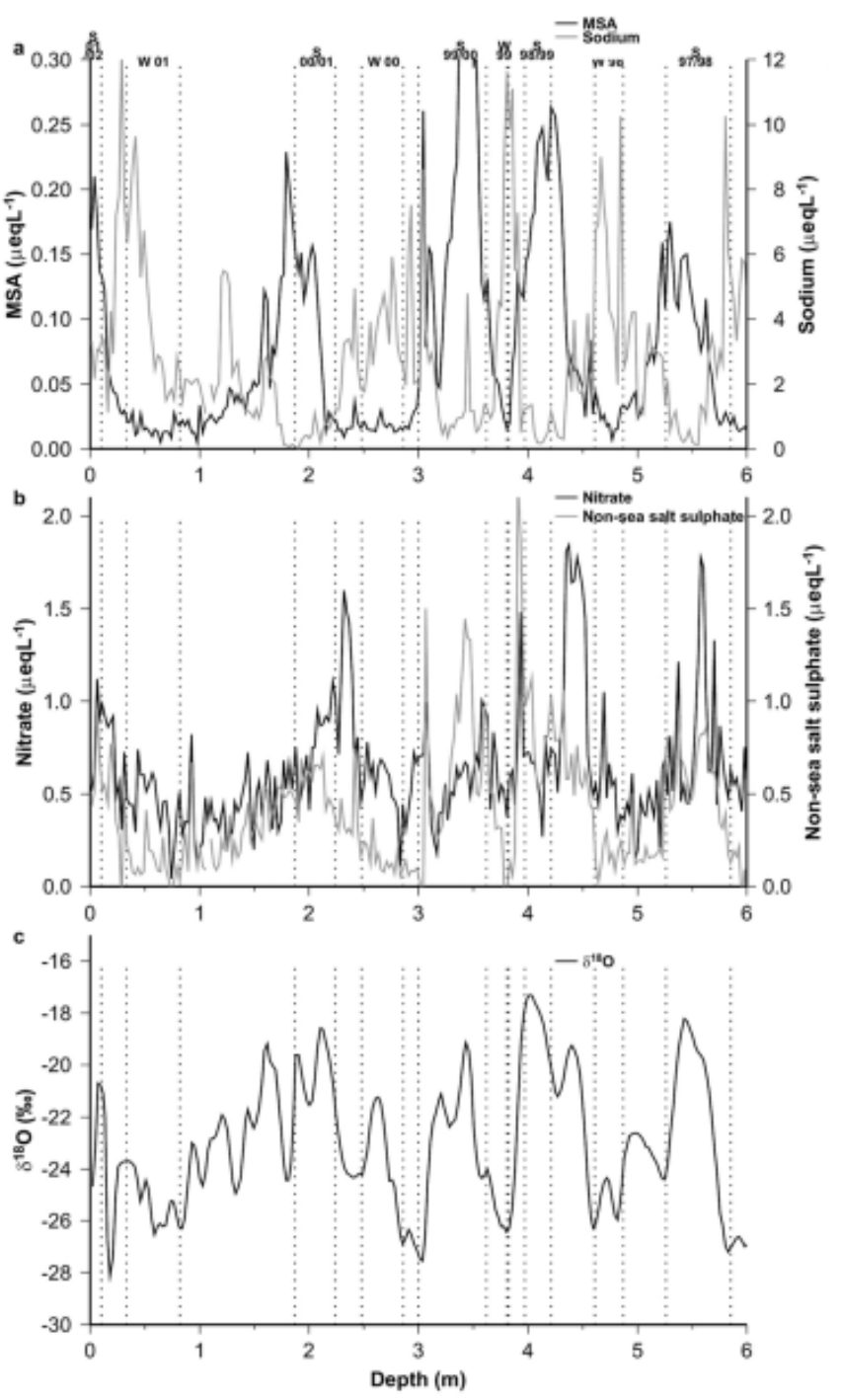

Fig. 5. Trace chemical and $\delta^{18} \mathrm{O}$ signals associated with the events preserved in DSS0102. (a) MSA, sodium; (b) nitrate, non-sea-salt sulphate; and (c) $\delta^{18} \mathrm{O}$. Seasonal (dotted) boundaries determined from the AWS but corrected for densification are also shown.

for producing enhanced sea-salt concentrations in the icecore record.

\section{Nitrate}

Nitrate shows a more erratic seasonal cycle characterized by narrow peaks during spring and early summer, and lower levels during late summer, autumn and winter (Fig. 5). Previous studies from Law Dome nitrate records have suggested that nitrate concentrations increase from June until a relative maximum is reached in November, with further sharp rises in concentrations until an absolute maximum is attained in January (Curran and others, 1998). However, the results presented here indicate nitrate maxima occur earlier in the year, and precede the main mid-summer $\delta^{18} \mathrm{O}$ and MSA peaks (Fig. 5). Similarly, high-resolution records from Siple Dome (Kreutz and others, 1999) and the coastal Antarctica stations of Mawson, Neumayer and Dumont d'Urville (Wagenbach and others, 1998b) show late-spring/early-summer enhancement of nitrate. Spring enhancement of nitrate is consistent with the transport of nitrogen species from the stratosphere to the troposphere through the weakening of the polar vortex at this time of 


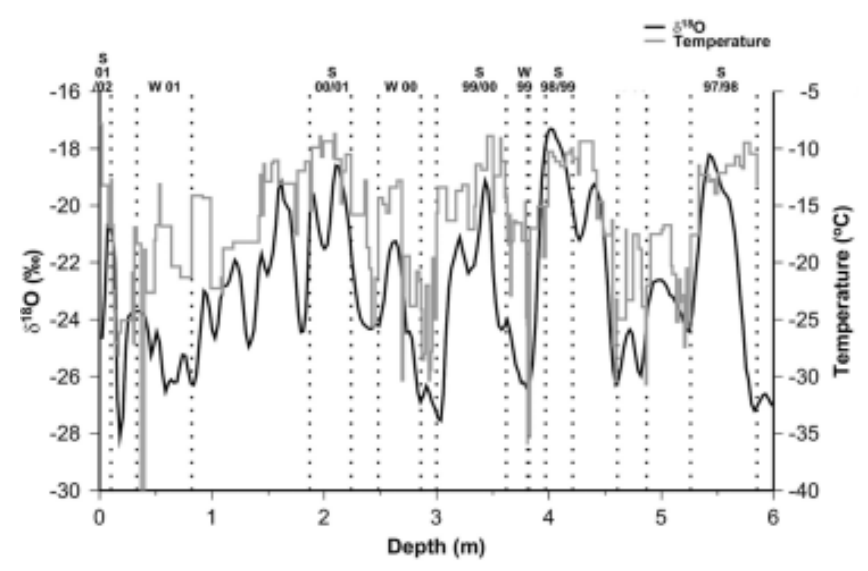

Fig. 6. $\delta^{18} \mathrm{O}$ and air temperatures associated with events preserved in DSS0102. Air temperatures correspond to daily averages for net accumulation days determined from the AWS accumulation record and thus represent a discontinuous record in time. Seasonal (dotted) boundaries determined from the AWS (corrected for densification) are also shown.

year. These results suggest the nitrate signal preserved in Law Dome ice cores is sourced from the stratosphere rather than local regions, although long-range tropospheric transport of nitrate cannot be ruled out.

\section{Non-sea-salt sulphate}

The non-sea-salt sulphate record preserved in DSSO102 shows a clear seasonal cycle with a pronounced midsummer maximum and lower concentrations during winter (Fig. 5). The summer maximum coincides with the main mid-summer peaks in MSA and $\delta^{18} \mathrm{O}$, and is consistent with marine biogenic sulphur compounds dominating the nonsea-salt sulphate signal at this time of year. However, outside the main mid-summer peak the non-sea-salt sulphate signal is more comparable to the nitrate record (Fig. 5). This indicates a common source for non-sea-salt sulphate and nitrate during spring, autumn and winter, with potential sources including the downward mixing of stratospheric air or long-range tropospheric transport.

\section{$\delta^{18} \mathrm{O}$}

The seasonal signal in $\delta^{18} \mathrm{O}$ preserved in DSSO102 is generally characterized by a narrow summer peak and broad winter trough (Fig. 5). All four years presented in Figure 6 show a maximum in $\delta^{18} \mathrm{O}$ occurring during midsummer, with smaller peaks occurring periodically throughout the seasonal cycle. These smaller $\delta^{18} \mathrm{O}$ peaks will diffuse over time and result in a smoothed record characterized by a broad seasonal signal in $\delta^{18} \mathrm{O}$ for deeper ice-core records. The seasonal cycle in $\delta^{18} \mathrm{O}$ presented in Figure 5 is in agreement with longer-term ice-core studies (Schotterer and others, 1997; van Ommen and Morgan, 1997) and compares well with the annual cycle in temperature for the East Antarctic region (Allison and others, 1993; van Ommen and Morgan, 1997).

Non-summer peaks in $\delta^{18} \mathrm{O}$ often occur during periods of enhanced sea-salt concentrations (Fig. 5), and indicate a common source of $\delta^{18} \mathrm{O}$ and sea salt unrelated to the seasonal cycle in temperature. Potential sources for the link between non-summer $\delta^{18} \mathrm{O}$ and sea salts include the intrusion of strong cyclonic events onto the Antarctic continent (McMorrow and others, 2001). The results presented in McMorrow and others (2001) suggest that cyclonic events facilitate the rapid advection of marine air from lower latitudes onto Law Dome. This rapid advection of low-latitude air provides an explanation for enhanced nonsummer $\delta^{18} \mathrm{O}$ signals, while strong winds associated with the cyclone direct sea-salt aerosols over the sampling site.

\section{COMPARING LOCAL METEOROLOGY WITH FIRN- CORE SIGNALS}

\section{Temperature and $\delta^{18} \mathrm{O}$}

Figure 6 compares the $\delta^{18} \mathrm{O}$ record from DSS0102 with associated air temperatures recorded by the co-located AWS. The temperature records correspond to daily averages for net accumulation days as determined from the AWS accumulation record, and thus represent a discontinuous record in time. Variations in $\delta^{18} \mathrm{O}$ preserved over the four annual cycles are in excellent agreement with observed variations in temperature at the coring site (Fig. 6). The narrow summer peak and broad winter trough in $\delta^{18} \mathrm{O}$ for all four years is reflected in the AWS air-temperature observations. In addition, many non-summer peaks in $\delta^{18} \mathrm{O}$ are also accompanied by peaks in air temperatures. This suggests a strong relationship between $\delta^{18} \mathrm{O}$ and air temperatures at Law Dome. The results are in agreement with van Ommen and Morgan (1997), who compare $\delta^{18} \mathrm{O}$ values from a composite seasonal signal calculated from 700 years of Law Dome data with a modern 5 year composite in air temperatures from an AWS $5 \mathrm{~km}$ north of the drilling site. However, this longer-term study only considers the broad seasonal cycle in $\delta^{18} \mathrm{O}$ as fine-resolution features such as non-summer peaks are smoothed by $\delta^{18} \mathrm{O}$ diffusion in the deep ice record. Figure 6 indicates a strong relationship between $\delta^{18} \mathrm{O}$ and air temperatures at Law Dome at a resolution finer than the annual cycle. In addition, Figure 6 provides a direct comparison between contemporaneous $\delta^{18} \mathrm{O}$ and site temperature observations on an event-by-event basis. Thus, the results presented here provide further evidence for the use of $\delta^{18} \mathrm{O}$ from deep ice cores as a proxy for palaeotemperatures.

The relationship between $\delta^{18} \mathrm{O}$ measurements and observed site temperatures can be used to calibrate the ice-core palaeothermometer. The dependence of observed $\delta^{18} \mathrm{O}$ measurements on temperature is generally well approximated by a linear relationship:

$$
\delta^{18} \mathrm{O}=\alpha T+\beta .
$$

The slope coefficient, $\alpha$, can be derived either from spatial variability over a region or from temporal variations at a site. A spatially derived slope of $0.6-0.7 \%{ }^{\circ} \mathrm{C}^{-1}$ has been determined for the Law Dome region (Morgan, 1979), and a temporally derived slope of $0.44 \%{ }^{\circ} \mathrm{C}^{-1}$ has been calculated from 700 years of annual cycles in $\delta^{18} \mathrm{O}$ at Law Dome (van Ommen and Morgan, 1997). More recent studies from a short length of Law Dome firn core examined the correlation between $\delta^{18} \mathrm{O}$ and temperature values on an event-by-event basis (McMorrow and others, 2001). In this study, a first attempt was made to account for the episodic nature of net accumulation and potential temperature biases preserved in the ice core. The temporal calibration determined from McMorrow and others (2001) yields a $\delta^{18} \mathrm{O}$ temperature slope of $0.21 \%{ }^{\circ} \mathrm{C}^{-1}$, and agrees with the 
finding from van Ommen and Morgan (1997) that temporally derived calibrations give lower slopes than spatially derived calibrations.

The similarity between the values calculated in this work and McMorrow and others (2001) indicates consistency in event-scale calibration between $\delta^{18} \mathrm{O}$ and temperature. The similar calibration coefficients calculated in each study provide evidence for the accuracy in determining temporal $\delta^{18} \mathrm{O}$ temperature calibrations using this event-by-event technique.

The observed slope of temporal calibrations will be influenced by isotopic diffusion in the firn column, which reduces the amplitude of the annual cycle in $\delta^{18} \mathrm{O}$. The calibration coefficients developed in McMorrow and others (2001) and this work are not corrected for isotopic diffusion in the firn. The degree to which diffusion affects $\delta^{18} \mathrm{O}$ values at shallow depths is not well understood, but may have decreased the amplitude of the $\delta^{18} \mathrm{O}$ annual cycle by up to $30 \%$, which is the integrated effect over the full firn column at DSS (van Ommen and Morgan, 1997). Therefore, the $0.24 \%{ }^{\circ} \mathrm{C}^{-1}$ calibration determined here may be corrected upwards at most by a corresponding factor. Correcting the $0.24 \%{ }^{\circ} \mathrm{C}^{-1}$ calibration upwards by $30 \%$ yields a maximum corrected coefficient of $0.31 \%{ }^{\circ} \mathrm{C}^{-1}$. This value is still considerably lower than the temporally derived value of $0.44 \%{ }^{\circ} \mathrm{C}^{-1}$ (corrected for diffusion) determined by van Ommen and Morgan (1997). Thus, correlating $\delta^{18} \mathrm{O}$ and temperature at the event level appears to reflect a genuine difference in the $\delta^{18} \mathrm{O}$ temperature calibration compared to longer-term, seasonally based studies.

The difference between the two temporal calibration techniques invites speculation as to the appropriate coefficient to use for interpretation of the longer-term $\delta^{18} \mathrm{O}$ record. Assuming that diffusion effects in the shallow firncore material used in this work can correct the event-scale coefficient of $0.24 \%{ }^{\circ} \mathrm{C}^{-1}$ upwards by a maximum of $30 \%$, then another explanation for the difference between this coefficient and the longer-term temporal calibration calculated by van Ommen and Morgan (1997) is required. A number of factors have been identified as likely contributors to lower temporal than spatial values for the $\delta^{18} \mathrm{O}$ temperature calibration, and these factors may also explain differences in temporal values. First, snowfall typically occurs when the temperature is warmer than average, and this has been shown to affect the temporal calibration (Peel, 1992). It is possible that the event-scale temporal calibration determined in this work accentuates the effects of such a temperature bias in the firn core. The calibration calculated by van Ommen and Morgan (1997) will be influenced by this warm-temperature bias during accumulation events. In contrast, the event-by-event calibration of $0.24 \%{ }^{\circ} \mathrm{C}^{-1}$ inherently accounts for the potential warm bias, as only temperatures associated with net accumulation events preserved in the firn core are used in the calculation. This will have the effect of increasing temperatures compared to $\delta^{18} \mathrm{O}$ values in the calibration, thus reducing the overall calibration coefficient.

Another important factor that will influence temporal $\delta^{18} \mathrm{O}$ temperature calibrations involves temperature variations at the moisture source. A change in temperature at both the source and deposition sites will reduce the relative temperature variation and lead to reduced fractionation and smaller fluctuations in the $\delta^{18} \mathrm{O}$ signal. The short-term study conducted here (four annual cycles) samples the modern climate regime for the Law Dome region. Temporal calibrations from long-term ice-core records sample a wide range of different climate regimes with greater variations in moisture source and deposition temperatures. Thus, these longer-term coefficients will include more fluctuations in climate cycles and may be more appropriate for calibrating the long-term isotope palaeothermometer.

\section{CONCLUDING REMARKS}

This paper explored the seasonal characteristics of chemical and isotopic species preserved in the ultra-high-resolution DSS0102 Law Dome ice core over four annual cycles. Accurate dating of DSS0102, obtained from the AWS accumulation record and adjusted for densification of the snowpack, enabled a detailed examination of the seasonal characteristics of the firn-core signals. The chronology of DSS0102 is unique compared to previous seasonality studies in that it was developed using net accumulation measurements independent of the seasonal cycle of the glaciochemical signals. This allowed, for the first time, the examination of calendar-based or absolute timings in the seasonality of each species rather than relative timings. The traditional summer-maximum species of $\delta^{18} \mathrm{O}$ and MSA show consistent relative phasing during mid-summer over the four annual cycles. Nitrate shows an erratic seasonal cycle with a general trend characterized by narrow peaks during spring and early summer, preceding the mid-summer peaks in $\delta^{18} \mathrm{O}$ and MSA. Non-sea-salt sulphate cycles indicate similar characteristics to MSA signals during summer, but are more comparable to nitrate signals during spring, autumn and winter. This suggests the summer non-sea-salt sulphate signal is driven by biological activity, although this species appears to be linked with nitrate signals outside the summer season. Finally, the sea-salt species indicate a seasonal cycle characterized by maximum concentrations during spring, winter and autumn. Local meteorological conditions recorded during net accumulation events were compared directly with the firn-core signals preserved in DSS0102. A strong relationship between $\delta^{18} \mathrm{O}$ and local air temperature was established at the event scale, providing evidence that Law Dome $\delta^{18} \mathrm{O}$ signals are driven by specific temperature events. The use of a range of glaciological and meteorological tools to examine the seasonality of ice-core signals enables a greater understanding of the application of these signals for the interpretation of palaeoclimate signals preserved in deeper ice-core records.

\section{REFERENCES}

Adams, N. 1996. The detection and analysis of a gravity wave observed over Casey in East Antarctica using radiosonde data. Austral. Meteorol. Mag., 45(4), 219-232.

Allison, I., G. Wendler and U. Radok. 1993. A climatology of the East Antarctic ice sheet $\left(100^{\circ} \mathrm{E}\right.$ to $\left.140^{\circ} \mathrm{E}\right)$ derived from automatic weather stations. J. Geophys. Res., 98(D5), 8815-8823.

Bradley, R.S. and P.D. Jones. 1993. "Little Ice Age" summer temperature variations: their nature and relevance to recent global warming trends. Holocene, 3(4), 367-376.

Bromwich, D. H. 1988. Snowfall in high southern latitudes. Rev. Geophys., 26(1), 149-168.

Curran, M. A. J. and A. S. Palmer. 2001. Suppressed ion chromatography methods for the routine determination of ultra low level anions and cations in ice cores. J. Chromatogr., Ser. A, 919(1), 107-113. 
Curran, M. A. J., T. D. van Ommen and V. Morgan. 1998. Seasonal characteristics of the major ions in the high-accumulation Dome Summit South ice core, Law Dome, Antarctica. Ann. Glaciol., 27, 385-390.

Delmotte, M., D. Raynaud, V. Morgan and J. Jouzel. 1999. Climatic and glaciological information inferred from air-content measurements of a Law Dome (East Antarctica) ice core. J. Glaciol., 45(150), 255-263.

King, J.C. and J. Turner. 1997. Antarctic meteorology and climatology. Cambridge, Cambridge University Press.

Kreutz, K.J. and 11 others. 1999. Seasonal variations of glaciochemical, isotopic and stratigraphic properties in Siple Dome (Antarctica) surface snow. Ann. Glaciol., 29, 38-44.

Legrand, M.R. and R.J. Delmas. 1984. The ionic balance of Antarctic snow: a 10 year detailed record. Atmos. Environ., 18(9), 1867-1874.

McMorrow, A. J., M. A. J. Curran, T. D. van Ommen, V. I. Morgan, M. A. J. Pook and I. Allison. 2001. Intercomparison of firn core and meteorological data. Antarct. Sci., 13(3), 329-337.

McMorrow, A. J., M. A. J. Curran, T. D. van Ommen, V.I. Morgan and I. Allison. 2002. Features of meteorological events preserved in a high-resolution Law Dome (East Antarctica) snow pit. Ann. Glaciol., 35, 463-470.

Minikin, A., D. Wagenbach, W. Graf and J. Kipfstuhl. 1994. Spatial and seasonal variations of the snow chemistry at the central Filchner-Ronne Ice Shelf, Antarctica. Ann. Glaciol., 20, 283-290.

Minikin, A. and 7 others. 1998. Sulfur-containing species (sulfate and methanesulfonate) in coastal Antarctic aerosol and precipitation. J. Geophys. Res., 103(D9), 10,975-10,990.

Morgan, V. 1979. Oxygen isotope analysis of Antarctic snow and ice. (M.Sc. thesis, University of Melbourne.)
Morgan, V. and T. D. van Ommen. 1997. Seasonality in late-Holocene climate from ice-core records. Holocene, 7(3), 351-354.

Morgan, V. I., C. W. Wookey, J. Li, T. D. van Ommen, W. Skinner and M. F. Fitzpatrick. 1997. Site information and initial results from deep ice drilling on Law Dome, Antarctica. J. Glaciol., 43(143), 3-10.

Palmer, A. S. 2002. Environmental signals from chemical measurements on Law Dome ice cores. (Ph.D. thesis, University of Tasmania. Institute of Antarctic and Southern Ocean Studies.)

Palmer, A. S., T.D. van Ommen, M. A. J. Curran and V. Morgan. 2001. Ice-core evidence for a small solar-source of atmospheric nitrate. Geophys. Res. Lett., 28(10), 1953-1956.

Peel, D. A. 1992. Ice core evidence from the Antarctic Peninsula region. In Bradley, R. S. and P. D. Jones, eds. Climate since A.D. 1500. London and New York, Routledge, 549-571.

Schotterer, U., K. Fröhlich, H.W. Gäggeler, S. Sandjordj and W. Stichler. 1997. Isotope records from Mongolian and Alpine ice cores as climate indicators. Climatic Change, 36(3-4), 519-530.

Schwerdtfeger, W. 1984. Weather and climate of the Antarctic. Amsterdam, Elsevier. (Developments in Atmospheric Science 15.)

Van Ommen, T. D. and V. Morgan. 1997. Calibrating the ice core paleothermometer using seasonality. J. Geophys. Res., 102(D8), 9351-9357.

Wagenbach, D., M. Legrand, H. Fischer, F. Pichlermayer and E. Wolff. 1998a. Atmospheric near-surface nitrate at coastal Antarctic sites. J. Geophys. Res., 103(D9), 11,007-11,020.

Wagenbach, D. and 7 others. 1998b. Sea-salt aerosol in coastal Antarctic regions. J. Geophys. Res., 103(D9), 10,961-10,974.

Whitlow, S., P. A. Mayewski and J. E. Dibb. 1992. A comparison of major chemical species seasonal concentration and accumulation at the South Pole and Summit, Greenland. Atmos. Environ., 26A(11), 2045-2054. 